KEMAS 12 (2) (2017) xx-xx
Jurnal Kesehatan Masyarakat

\title{
THE CHILDBIRTH SERVICES ASPECT THAT INFLUENCE PATIENT SATISFACTION
}

\author{
Hema Dewi Anggraheny ${ }^{1 \bowtie}$, Sudiro $^{2}$ \\ ${ }^{1}$ Faculty of Medicine, Universitas Muhammadiyah Semarang \\ ${ }^{2}$ Faculty of Public Health, Universitas Diponegoro, Semarang
}

\section{Article Info}

Article History:

Submitted 30 September 2016 Accepted 16 Desember 2016 Published Januari 2017

Keywords:

childbirth services; birth satisfaction; patient satisfaction

DOI

http://dx.doi.org/10.15294/ kemas.v11i1.3521

\begin{abstract}
Pregnant women have higher expectations of the care providers attitude in order to have childbirth satisfaction. This study aims to analyze the relationship between childbirth services and birth satisfaction in Roemani Muhammadiyah Semarang hospital. We used a cross sectional design and used an interview to collect the data, it was conducted from July to August 2016. A total of 79 women were enrolled in the study that fulfill the inclusion and exclusion criteria. The childbirth services and patient satisfaction were measured using survey instruments which we'd measured the reliability and validity previously. The linier regression were applied. The majority of the patients $(94,9 \%)$ were 21 -40 years old, $67,1 \%$ were university graduate, $40,5 \%$ were housewife, $62 \%$ were multigravida, and $57 \%$ were delivered by cesarean section. There were significant effect between interpersonal relationship $(p=0,0001)$, patient decision choice $(p=0,001)$, and breastfeeding management $(\mathrm{p}=0,021)$ and birth satisfaction. The strongest predictor of birth satisfaction was interpersonal relationship.
\end{abstract}

\section{Introduction}

The potential for increasing the numbers of childbirth services at hospitals especially at private hospitals is currently wide open with the opportunity to cooperate with BPJS Kesehatan. Pregnant women with JKN (National Health Insurance) member can use her right to choose any place of delivery at health facilities in collaboration with BPJS. It makes a lot of private hospitals to compete to improve the quality of childbirth service in order to attract patients as many as possible.

Good delivery services will affect patient satisfaction (Duong, 2004; Bitew, 2015;
Attanasio, 2014). Many factors may affect childbirth services satisfaction. Beside to the safety of mothers and babies, satisfaction also may reached if the service provider can provide services according to the expectations and needs of the patient. There are three important things that affect labor satisfaction, such as the quality of delivery services, personal characteristics of the patient, and the patient stress during labor (Martin, 2011).

Based on the Women's Health Journal, delivery services cover six dimensions of services, which are women-centered, safe, effective, on time, efficient, and equitable (equal 
rights and responsbility for each patient). Aspects of the services being assessed include physical and emotional support, interpersonal relationships, patient decision choice, pain management, the professionalism of the medical team, and management of lactation (Carter, 2010; Angood, 2010; Lowe 2010). With good services, it is expected to reduce maternal and infant mortality, provide satisfaction, as well as the comfort and safety for mothers, babies and their families (Carter, 2010).

In 2014, there were 26 hospitals in Semarang which consist of 14 private hospitals, 7 public hospitals, 3 mother and child hospitals, 1 maternity hospitals and 1 psychiatric hospital. In 2015, there was addition one hospital (Semarang City Public Health Office 2015). With a fairly large number of hospitals created strict competition among hospitals, especially in providing delivery services as optimal as possible, so resulting in patient satisfaction and loyalty.

Roemani Muhammadiyah Hospital Semarang is a class $C$ private hospital located in South Semarang area which is densely populated areas. Roemani Hospital has strategic location, which is located in the center of city, so it has great potential for reaching the population in the health services. Roemani Hospital also take advantage of the opportunities by cooperate with BPJS since January 2014.

Based on data from Roemani Hospital medical records, there is an increasing number of births in Roemani Hospital from 2013 to 2014. There are 834 deliveries in 2013 and increased in 2014 to 866 deliveries, however in 2015 decreased to 787 deliveries. The increases in 2014 possibly due to the launching of the National Health Insurance by BPJS, and dividing the area into several zone for JKN member with provision that maternity patients are referred to a referral hospital chosen by BPJS (zone according to living area). In 2015, these provisions were eliminated, so that patients can freely choose the referral hospital will be addressed. Most of the patients in 2015 using $\mathrm{JKN}$, with a percentage of $60 \% \mathrm{JKN}$ members and $40 \%$ of general patients.

Collaboration with BPJS is an opportunity for hospitals to survive and even thrive in the era of health globalization. On behalf of government program that Indonesian citizens is supposed to be enrolled in BPJS Kesehatan by 2019. With the high opportunity, the hospital should provide a high quality services in order to improve patient satisfaction and loyalty. However, trends alteration in the delivery patients do not necessarily lead to changes in the quality of services at the Roemani Hospital. This is indicated by the number of maternity patients decreased in 2015 and there are complaints related to service delivery.

Any complaints related to patient care delivery obtained from the Public Relation Division data of Roemani Hospital in 2015 and a preliminary study on 10 postchildbirth patients conducted in March 2016. The predominant complaint include limited parking facilities, lack of privacy given by the hospital (husband or family can not accompany during of childbirth), unfriendly attitude of officers, and the food menu is bland and lacking in variety.

These patient's complaints if not followed up by the hospital, it may lead to decreased numbers of patients. In addition refers to various studies, consumers who filed complaints and felt the complaint is not resolved satisfactorily, will tell about the treatment they received at averages of five people (Hildingsson, 2013).

The problem in this research is a declining in the number of deliveries in 2015. The majority of patients in 2015 using JKN with $60 \%$ patients using JKN, and $40 \%$ general patients. There are also complaints of patients in 2015 and 2016 include the limited facilities, unfriendly officers, less effective communication, lack of education, and drugs that are not covered by BPJS. The purpose of this study is to analyze the impact of delivery services to the patient satisfaction in Roemani Muhammadiyah Hospitals Semarang.

\section{Method}

We used quantitative analytical observational approach with cross sectional design. Subjects of this study were 79 patients with post-childbirth in the Maternity Unit of Roemani Muhammadiyah Hospital Semarang. Data was collected through interviews using a structured questionnaire, which has been tested for validity and reliability. For measurement variable scale, we used semantic differential 
Table 1. Participants Characteristics

\begin{tabular}{|c|c|c|c|}
\hline No & Characteristics & Frequency & $\%$ \\
\hline \multirow[t]{4}{*}{1} & \multicolumn{3}{|l|}{ Education } \\
\hline & - $\quad$ Junior high school & 3 & 3,8 \\
\hline & Senior high school & 23 & 29,1 \\
\hline & University & 53 & 67,1 \\
\hline \multirow[t]{6}{*}{2} & \multicolumn{3}{|l|}{ Occupation } \\
\hline & - $\quad$ Private employee & 29 & 36,7 \\
\hline & Civil servants & 15 & 19 \\
\hline & Entrepreneur & 2 & 2,5 \\
\hline & Students & 1 & 1,3 \\
\hline & Housewife & 32 & 40,5 \\
\hline \multirow[t]{4}{*}{3} & \multicolumn{3}{|l|}{ Parity } \\
\hline & Primigravida & 30 & 38 \\
\hline & Multigravida & 49 & 62 \\
\hline & Grande Multipara & 0 & 0 \\
\hline \multirow[t]{4}{*}{4} & \multicolumn{3}{|l|}{ Delivery method } \\
\hline & - $\quad$ Spontaneous & 32 & 40,5 \\
\hline & Vacuum/forceps & 2 & 2,5 \\
\hline & Sectio caesarea & 45 & 57 \\
\hline
\end{tabular}

Source: Primary Data

scale range from 0-10. Data was analyzed using simple linear regression test and multiple linear regression. This study has been approved by the ethical committee of Faculty of Public Health Diponegoro University on June 30th, 2016, with serial number 160 / EC / FKM / 2016.

\section{Results and Discussion}

Participants characteristics included age, education level, occupation, parity, and delivery methods. The majority of participants were in early adult age group (21-40 years) $(n=75$, 94.9\%). The remaining four people (5.1\%) were in the middle age group (41-60 years). No participants were aged $<20$ years or $>60$ years.

Table 1 showed that most participants was university graduates background (67.1\%), housewives (40.5\%), multigravida (62\%), and with sectio caesarea delivery method (57\%).

In general, the mean score of delivery services in the Maternity Unit of Roemani Muhammadiyah Hospital Semarang was $>7$ from the range of $0-10$. Table 2 showed the service which below average which was to provide opportunity for the husband / family to accompany the patient during childbirth, the waiting time of patients initial service, the information delivered by officers about advantages and disadvantages of childbirth method taken with explanation sheets and informed consent, the information related to relaxation and breathing techniques to reduce labor pain, as well as the technical explanation for Early Initiation of Breastfeeding (IMD) immediately after birth.

Table 3 showed the participants responses toward satisfaction of delivery services, which was assessed on the aspects of satisfaction on delivery services procedures, facilities, interpersonal care, and access to services. Total average satisfaction was 8.09 on the 0-10 range. The majority of patient satisfaction ratings in Roemani hospital had a value above the total average. It meant that most patients who take advantage of delivery service in Roemani Hospital already feel satisfied with the services provided. However, it is required more attention in those aspects that have a value below the average to know more about the expectations of patients.

Based on Table 4, it showed the relationship between the physical and emotional support variables with the patient satisfaction 
Table 2. Assesments of Participants Responds on each Variable of Delivery Services

\begin{tabular}{|c|c|c|c|c|c|c|}
\hline No. & Variable & $\begin{array}{l}\text { Total } \\
\text { Mean }\end{array}$ & Highest mean & Score & Lowest mean & Score \\
\hline 1. & $\begin{array}{l}\text { Physi- } \\
\text { cal and } \\
\text { emotional } \\
\text { support }\end{array}$ & 7,96 & $\begin{array}{l}\text { Health worker give moti- } \\
\text { vation on behalf of deliv- } \\
\text { ery }\end{array}$ & 8,61 & $\begin{array}{l}\text { Give opportunity to } \\
\text { husband of family to } \\
\text { accompany patients in } \\
\text { delivery room }\end{array}$ & 7,21 \\
\hline 2. & $\begin{array}{l}\text { Interper- } \\
\text { sonal rela- } \\
\text { tionship }\end{array}$ & 7,79 & $\begin{array}{l}\text { Health worker looked neat } \\
\text { and clean }\end{array}$ & 8,53 & $\begin{array}{l}\text { Waiting time for pa- } \\
\text { tients initial service } \\
\leq 15 \text { minutes }\end{array}$ & 7,70 \\
\hline 3. & $\begin{array}{l}\text { Patient } \\
\text { decision } \\
\text { choice }\end{array}$ & 7,90 & $\begin{array}{l}\text { Health worker provide op- } \\
\text { portunity to patient to de- } \\
\text { cide based on her health } \\
\text { status and her child with- } \\
\text { out any charges and may } \\
\text { change his mind without } \\
\text { any sanction. }\end{array}$ & 8,03 & $\begin{array}{l}\text { Patients get a sheet ex- } \\
\text { planation of her con- } \\
\text { dition and approval of } \\
\text { selection of actions to } \\
\text { be taken }\end{array}$ & 7,70 \\
\hline 4. & $\begin{array}{l}\text { Pain man- } \\
\text { agement }\end{array}$ & 7,94 & $\begin{array}{l}\text { Management of pain after } \\
\text { childbirth (postpartum) } \\
\text { provided by health worker } \\
\text { help reduce the pain felt } \\
\text { by the patient }\end{array}$ & 7,97 & $\begin{array}{l}\text { The health worker give } \\
\text { explanation on re- } \\
\text { laxation and breathing } \\
\text { techniques to reduce } \\
\text { pain }\end{array}$ & 7,91 \\
\hline 5. & $\begin{array}{l}\text { Lactation } \\
\text { manage- } \\
\text { ment }\end{array}$ & 7,93 & $\begin{array}{l}\text { Mother and baby are al- } \\
\text { ways together in one room }\end{array}$ & 8,59 & $\begin{array}{l}\text { Health worker pro- } \\
\text { vide explanations and } \\
\text { the early initiation of } \\
\text { breastfeeding immedi- } \\
\text { ately after birth }\end{array}$ & 7,58 \\
\hline
\end{tabular}

Source: Primary Data

Table 3. Assesment of Participant Responds Toward Satifaction Variables

\begin{tabular}{|c|c|c|c|c|c|c|}
\hline No. & $\begin{array}{l}\text { Satisfaction } \\
\text { aspects }\end{array}$ & $\begin{array}{l}\text { Total mean of } \\
\text { satisfaction }\end{array}$ & Highest mean & Score & Lowest mean & Score \\
\hline 1 & $\begin{array}{l}\text { Procedure } \\
\text { of delivery } \\
\text { service }\end{array}$ & 8,09 & $\begin{array}{l}\text { The efforts towards } \\
\text { healing and pa- } \\
\text { tient safety }\end{array}$ & 8,41 & $\begin{array}{l}\text { Waiting time for pa- } \\
\text { tients to get services }\end{array}$ & 7,68 \\
\hline 2 & Facilities & & $\begin{array}{l}\text { Cleanliness ofde- } \\
\text { livery room }\end{array}$ & 8,30 & Spacious parking space & 7,19 \\
\hline 3 & $\begin{array}{l}\text { Interper- } \\
\text { sonal as- } \\
\text { pects of } \\
\text { care }\end{array}$ & & $\begin{array}{l}\text { Explanation of pa- } \\
\text { tient's health con- } \\
\text { dition }\end{array}$ & 8,32 & $\begin{array}{l}\text { The time devoted to } \\
\text { patient care }\end{array}$ & 7,96 \\
\hline 4 & $\begin{array}{l}\text { Access to } \\
\text { services }\end{array}$ & & $\begin{array}{l}\text { The ease of getting } \\
\text { drugs }\end{array}$ & 8,24 & - & - \\
\hline
\end{tabular}

Source: Primary Data 
Table 4 Simple Linier Regression Test on Delivery Services and Patient Satisfaction

\begin{tabular}{llllllll}
\hline Independent Variables & R value & $\begin{array}{l}\mathrm{R} \\
\text { Square } \\
\text { value }\end{array}$ & $\begin{array}{l}\mathrm{p} \\
\text { (ANO- } \\
\text { VA) }\end{array}$ & $\begin{array}{l}\text { Constan- } \\
\text { ta }\end{array}$ & $\begin{array}{l}\text { Stand coeff } \\
\beta\end{array}$ & (coeff) \\
\hline $\begin{array}{l}\text { Physical and emotional } \\
\text { support }\end{array}$ & 0,742 & 0,550 & 0,0001 & 55,235 & 0,742 & 0,0001 \\
$\begin{array}{l}\text { Interpersonal relationships } \\
\text { Patient decision choice }\end{array}$ & 0,904 & 0,817 & 0,0001 & 10,472 & 0,904 & 0,0001 \\
Pain management & 0,882 & 0,777 & 0,0001 & 33,557 & 0,882 & 0,0001 \\
Lactation management & 0,7682 & 0,465 & 0,0001 & 86,064 & 0,682 & 0,0001 \\
\hline
\end{tabular}

Source: Primary Data

Table 5 Multiple Linear Regression Test

\begin{tabular}{lllllll}
\hline Independent Variable & $\mathrm{R}$ value & $\begin{array}{l}\mathrm{R} \\
\text { Square } \\
\text { value }\end{array}$ & $\begin{array}{l}\mathrm{p} \\
\text { (ANO- }\end{array}$ & $\begin{array}{l}\mathrm{p} \text { (coef- } \\
\text { ficients) }\end{array}$ & Constanta & $\begin{array}{l}\text { Stand coeff } \\
\beta\end{array}$ \\
& & 0,869 & 0,0001 & 0,0001 & 10,555 & 0,524 \\
Interpersonal relationships & 0,932 & $0,0,001$ & & 0,314 \\
Patient decision choice & & & & 0,01 & 0,154 \\
Lactation management & & & & 0,021 & & 0 \\
\hline
\end{tabular}

Source: Primary Data

was strongly positive; the relationship between the variables of interpersonal relationships and professionalism with patient satisfaction was very strongly positive; the relationship between the variables of patient decision choice with patient satisfaction was strongly positive; the relationship between the variables of management pain with patient satisfaction was sufficiently positive; and the relationship between variables of lactation management and patient satisfaction was strongly positive. The highest $\mathrm{R}$ value obtained on the variables of interpersonal relationships and professionalism, while the lowest was in pain management.

Table 4 showed that the physical and emotional support, interpersonal relationships and professionalism, patient choice decision, pain management, and management of lactation to client satisfaction had significant level $0.0001(<0.005)$. It concluded that $\mathrm{H} 0$ was rejected and $\mathrm{H} 1$ were accepted, so there were significant association between physical and emotional support, interpersonal relationships and professionalism, patient choice decision, pain management, and management of lactation toward patient satisfaction.

Based on Table 5 it could be shown that the number $\mathrm{R}$ of 0.932 indicated a relationship between the variables of interpersonal relationships and professionalism, patient decision choice and lactation management and patient's satisfaction was strongly positive. Coefficients of $p$ value, indicating that the three variables of interpersonal relationships and professionalism, patient choice decision, and management of lactation were able to significantly influence patient satisfaction (sig $<0.05$, Ho is rejected).

Patient satisfaction that had a value below the average was the facility and interpersonal services. Patient satisfaction aspects of the facility which was rated below average were satisfaction of the adequacy of parking area, bathroom cleanliness, comfortable wards, bathroom facilities can function normally, as well as the cleanliness of the wards. While the interpersonal aspects of care was the satisfaction of staff time devoted to patient care. Patients rate the officers already perform ministerial duties, but the time devoted to such 
services insufficient to meet all the needs and wishes of patients.

The results of the study in Roemani hospital about testing the effect of variable physical and emotional support toward the satisfaction mentioned that most of the patients give score above average for each item of physical and emotional support services. Most patients assessed the cleanliness of wards, a functioning bathroom, cleanliness of the bathrooms, nutritional adequacy, and completeness of drug administered by the hospital was good enough to meet the patient's needs. Besides emotional support from health worker also felt enough for the patient. Emotional support was also provided to allow the husband / the patient's family to accompany the patient during delivery, although not all patients get the same treatment.

Statement of service of variable physical and emotional support that was below the average were the opportunity for a husband I family to accompany the patients during delivery, comfortable wards, bathroom cleanliness, and wards cleanliness. Policy given by the hospital that the opportunity to accompany the patient during labor depending on birth attendant physician. This was a concern for some patients, because of the support of those closest to the patient resulting comfortable feeling and reduce patient anxiety towards labor (Elisa, 2012).

The results of this study were consistent with the opinion of other researchers, as well as some literature which said that the physical and emotional support affect the satisfaction of labor (Tayelgn, 2011; Melese , 2014, Mekonnen, 2015; Hildingsson, 2013; Elisa, 2012). Delivery satisfaction study conducted by Mekonnen, also mentioning that equipped tools, cleanliness and comfortable wards, as well as the cleanliness of the bathroom quite enough to contribute to the satisfaction of delivery services (Mekonnen, 2015).

Patients in Roemani hospital also felt that with equipped facilities and technologies resulting in secure feeling and satisfied. Patients believed in the ability of hospitals to solve the problems of patient delivery. This was consistent with research by Tricas JG (2011), mentioned that the main factors that lead to the satisfaction of labor, such as equipped facilities and technologies from the service provider that will generate trust and secure feeling for the patient. In that study, patients believed with equipped facilities and cutting-edge technology may guarantee the security and safety of mother and baby.

There was positive effect and significant relationship of the effect of interpersonal relationships with satisfaction. Interpersonal relationships included good communication and a trust that exists between hospital personnel and patients, the treatment of the patient as a partner, as well as the opportunity provided for patients to express their wishes in medical decision-making related to their baby delivery.

Most patients believed to health personnel to provide care for her. Patients also assessed good on communication, humanistic, and performance of health personnel. Aspects of interpersonal relationships was most important things of satisfaction of Roemani hospital in childbirth services. This was in line with research conducted by Melese $\mathrm{T}$ (2014), stated that the communication, the information provided by health personnel to the patient, attitude, friendly and empathy given, and the privacy given to the examination affect patient satisfaction. Similarly, research conducted by Tricas JG (2014), mentioning the main pillars of the satisfaction of delivery services such as humanism dimension and the relationship between health personnel and the patient. It included attitude and friendliness of the health personnel, professionalism, and communication.

Statements of services that below the average was related to waiting time to the patient's initial services. The ideal waiting time for delivery services is $\leq 15$ minutes (Paudel, 2015). Most delivery patients get through the emergency department, so the response time should be fast. Based on the interviews, most of the health personnel had done their job by providing initial services less than 15 minutes. However, there were some participants stated that slow initial service was caused patients come during health personnel shift hours.

There was positive influence and significant association between patient decision 
choices with patient satisfaction. Patient decision choice was an opportunity given by service providers to pick and choose the best decision for her care, with medical personnel guidance (Carter, 2010; Lowe 2010).

This study resulted that the patient had given the opportunity to determine decisions on their care. Health personnel also provided information regarding the conditions and management will be performed. Patients felt being involved in making decisions, with health personnel provided information about advantages and disadvantages of the action will be performed.

Statement of variable patient choice decision were below the average such as information given by the health personnel related to advantages and disadvantages of action performed with an explanation sheet and informed consent. Based on the interviews, patients who get surgery most of them get an explanation, though not all of them believed that the explanation is also written together in the informed consent signed to patient before the procedure performed. But for patients with normal labor, majority not provided the information and forms that must be signed.

This was in line with research conducted by Attanasio LB et al, which mentioned the results of qualitative analysis showed that the one that produce satisfaction of labor and provide a positive experience in childbirth such as the opportunity given to patient in making medical decisions (Attanasio, 2014). Based on this studies, the patients were satisfied when given an explanation and were involved in making medical decisions on action to be taken (Attanasio, 2014). According to Lawrence HC, that patient involvement in decision-making over her treatment performed previously by providing enough information to be able to make choices, and to cooperate with the health personnel (Lawrence, 2012). With the information and the opportunity provided by health personnel, the patient will felt more respected and listened. It was a psychically will lead to satisfaction, reduce the risk of lawsuits in case of unexpected outcomes, and cause compliance in the treatment (Attanasio, 2014; Lawrence, 2012).

There was positive influence and significant association between pain management and patient satisfaction. Management of pain was a strategy both pharmacologic and non-pharmacologic given to patients as effectively as possible. The results of the research showed that most patients also assessed pain management in this hospital already help patients relieved the pain problems.

The result of the participants' answers indicated that in patients performed sectio caesarean delivery techniques, the pain management better than vaginal delivery. It may still be possible for a patient due to association between pain management toward the impact pain intensity perceived. Most patients who performed vaginal delivery did not get medical treatment during delivery and post delivery. Whereas in patients with surgery mostly get medical treatment after birth. Patients can also be satisfied if the perceived pain reported to the health personnel, and the health personnel can respond it. .

According to Hodnett (2002), who wrote several studies related to pain management and labor satisfaction that relieve the pain with satisfaction of pain management was a different thing. Relieve the pain associated with pain intensity of each individual, complications of the illness, as well as the response to pain reduction from interventions given. Patients would tend to be satisfied if it can convey the pain that she felt, to get information in the handling of such pain, involved in her pain management, as well as the pain management can help patients deal with anxiety, thereby reducing the pain felt (Hodnett, 2002; Attanasio, 2014; Lally, 2014).

There was positive influence and significant association of the lactation management with patient satisfaction. Health personnel in Roemani Hospital provided support and information of the technical process and good breastfeeding for the mother, and early initiation of breastfeeding process as soon as possible after birth. Mothers and the baby should not be separated by more than 2 hours after birth. But it was still information only, and was not followed by a personal evaluation of whether the patient has been able to actually apply these techniques. With good management of lactation according to the procedure above, can increase the trust 
of mothers in breastfeeding their babies, particularly for primiparous mother, which is expected to lead to a positive experience.

Statement of service of variable management of lactation were below average that was the information to the mother and baby to do a skin to skin contact immediately after delivery for at least 1 hour, mothers and babies were not separated for more than two hours after delivery, as well as the technical information about early initiation of breastfeeding (IMD). Mothers get an explanation to always apply a skin to skin contact for at least 1 hour after delivery, to make good connection to the baby, and healing after childbirth. Based on the interviews, most of the patients got an explanation regarding the technique, however applied only less than 1 hour, especially for the postoperative patients. Many of the participants did not understand the process. Similarly, the IMD that was performed, most of the postoperative patients assessed less for information about IMD by health personnel.

The statement needs to be considered for the hospital and the patient. By doing IMD, skin to skin contact and care together as soon as possible after delivery will cause connection and quick adaptation between mother and baby, increasing the prolactin hormone, which will increase milk production, reduces the risk of infection in infants, increase the contractility of the uterus, as well as help post-childbirth healing for mother both vaginal and operative delivery.

This was consistent with study conducted by Dykes $\mathrm{F}$ et al stated that the delivery service providers also need to consider the lactation management of patients. The management included support for the needs of breastfeeding mothers and infants as recovery for the mother and the infant's nutritional needs, emotional support to keep breastfeeding for mothers without the addition of formulation milk, recognition for mothers who breastfeed, facilities that support breastfeeding mothers, as well as sufficient information on breastfeeding (Dykes et al. 2003).

A similar study conducted by Raharjo $\mathrm{BB}$ and Digirolamo AM et al suggested that the management of early breast-feeding is good, it will provide a positive experience for both mother and support mothers to breastfeed exclusively, and can even keep breastfeeding up to 2 years. In the study, lactation management of the hospital as a delivery service provider to use the concept of "Baby Friendly Hospital" by carrying the 10 steps lactation management. Managing concept of "Baby Friendly Hospital" is the concept of service lactation initiated by WHO and UNICEF since 1991, which is expected to be implemented in all maternity services providers (Rahardjo, 2014; Wambach 2005; Digirolamo, 2008).

Aspects of delivery services that had significant effect on satisfaction after tested together were interpersonal relations, decision patient choice and lactation management. From the statistical results can be concluded that this aspect of interpersonal and professional relationships had the most impact on satisfaction. This was consistent with other research that said that the most important factors of satisfaction with delivery services and the relationship of trust and communication. From good communication will encourage patient trust and will lead to safety, comfort, and satisfied feeling (Carter, 2010).

Malender HL in a journal written by Melese $\mathrm{T}$ et al, stated that pregnant women had high expectations of the labor workforce in order to get satisfactory delivery. All aspects of service delivery which included physical and emotional support, interpersonal relationships, patient choice decision, pain management, and lactation management were specific aspects that should be considered for delivery service providers (Melese, 2014).

Participants characteristics such as the number of parity, and delivery techniques can also affected satisfaction. In this study, primigravid patients assessed higher satisfaction perceived compared to multigravida patients. This was likely due to primigravida patients couldn't compare with the previous delivery, whereas patients multigravida could compare with previous childbirth experience.

\section{Conclusion}

Among the factors that influenced satisfaction of delivery services such as physical and emotional support, interpersonal relationships, patient choice decision, pain management, and lactation management of 
patients showed that the most significant relationship was interpersonal relationships. The result of multivariate analysis showed that acceptable variable were variable interpersonal relationships and professionalism, patient decision choice and lactation management. Of the three variables which were able to predict the most significant for satisfaction of patients was interpersonal relationships variable. Participant answer from interpersonal relationships and professional variables mentioned that participant assessed the highest services was the appearance of health personnel, and service with the lowest score was the waiting time for initial patient care. These results supported some earlier studies on birth satisfaction which showed that the most important factors of satisfaction in delivery services was the trust relationship and communication between the patient and health personnel.

\section{Referrences}

Angood, P.B. et al., 2010. Blueprint for Action. Steps Toward a High-Quality, High-Value Maternity Care System, Jacobs Institute of Women's Health.

Attanasio, L.B., McPherson, M.E. \& Kozhimannil, K.B., 2014. Positive childbirth experiences in US hospitals: A mixed methods analysis. Maternal and Child Health Journal, 18(5) : 1280-1290.

Bitew, K., Ayichiluhm, M. \& Yimam, K., 2015. Maternal Satisfaction on Delivery Service and Its Associated Factors among Mothers Who Gave Birth in Public Health Facilities of Debre Markos Town, Northwest Ethiopia. BioMed Research International : 1-7.

Carter, M.C. et al., 2010. 2020 Vision for A HighQuality, High-Value Maternity Care System. Women's Health Issues, 20 (1) : 7-17.

DiGirolamo, A.M., Grummer-Strawn, L.M. \& Fein, S.B., 2008. Effect of maternity-care practices on breastfeeding. Pediatrics, 122 : 43-S49.

Dinas Kesehatan Kota Semarang, 2015. Profil Kesehatan Kota Semarang 2014.

Duong, D. Van et al., 2004. Measuring client perceived quality of maternity services in rural Vietnam. International Journal for Quality in Health Care, 16 (6) : .447-452.

Dykes, F. et al., 2003. Adolescent mothers and breastfeeding: experiences and supportneeds - an exploratory study. Journal of Human Lactation, 19(4), pp.391-401.

Elisa, Parwati, D.M. \& Sriningsih, I., 2012. Pengalaman Ibu Yang Terdeteksi HIV
Tentang Dukungan Keluarga Selama Persalinan. Jurnal Kesehatan Masyarakat, $8(1)$ : 35-41.

Goberna-Tricas, J. et al., 2011. Satisfaction with pregnancy and birth services: The quality of maternity care services as experienced by women. Midwifery, 27 (6) : 231-237.

Hildingsson, I. et al., 2013. Women's satisfaction with antenatal care: Comparing women in Sweden and Australia. Women and Birth, 26 (1) : e9-e14.

Hodnett, E.D., 2002. Pain and women's satisfaction with the experience of childbirth: A systematic review. American Journal of Obstetrics and Gynecology, 186 (5) : 160-174.

Lally, J.E. et al., 2014. Pain relief in labour: a qualitative study to determine how to support women to make decisions about pain relief in labour. BMC pregnancy and childbirth, 14 (1) $: 6$.

Lawrence, H.C. et al., 2012. Quality patient care in labor and delivery: A call to action. American Journal of Obstetrics and Gynecology, 207 (3) : 147-148.

Lowe, N.K., 2010. Transforming Maternity Care. JOGNN - Journal of Obstetric, Gynecologic, and Neonatal Nursing, 39 (3) : 235-237.

Martin, C.H. \& Fleming, V., 2011. The birth satisfaction scale. International journal of health care quality assurance, 24 (2) : 124135.

Mekonnen, M.E., Yalew, W.A. \& Anteneh, Z.A., 2015. Women's satisfaction with childbirth care in Felege Hiwot Referral Hospital, Bahir Dar city, Northwest Ethiopia, 2014: cross sectional study. BMC research notes.

Melese, T. et al., 2014. Assessment of client satisfaction in labor and delivery services at a maternity referral hospital in Ethiopia. Pan African Medical Journal, $17: 2-9$.

Paudel, Y.R. et al., 2015. Women's Satisfaction of Maternity Care in Nepal and Its Correlation with Intended Future Utilization. International journal of reproductive medicine

Rahardjo, B., 2014. Profil Ibu dan Peran Bidan dalam Praktik Inisiasi Menyusui Dini dan ASI Eksklusif. Jurnal Kesehatan Masyarakat, 10 (1) : 53-63.

Tayelgn, A., Zegeye, D.T. \& Kebede, Y., 2011. Mothers' satisfaction with referral hospital delivery service in Amhara Region, Ethiopia. BMC Pregnancy Childbirth, 11(1) : 78

Wambach, K., 2005. Clinical Lactation Practice: 20 Years of Evidence. Journal of Human Lactation, 21(3) : 245-258. 